\title{
GREAT HORNED OWL NEST SITES IN SASKATCHEWAN
}

\author{
C. STUART HOUSTON, 863 University Drive, Saskatoon, SK. S7N 0J8
}

Note: The indulgence of the reader is requested for the use of imperial measurements of heights. It strikes me as foolish to convert estimates of nest height, begun before the introduction of metric measurements, into fractions of metres.

Owls and falcons do not build their own nests. We know that Prairie Falcons can be attracted to a new territory by a man-made hole in a dirt cliff. Although prey availability is the prime consideration, 5 my observations suggest that a beginning pair of Great Horned Owls similarly are more likely to choose a territory if it contains a sturdy Red-tailed Hawk nest; such nests may be even more attractive when remote from human activity. When owls are on the upward slope of their 10-year population cycle, ${ }^{4}$ we see virtually no owls except at nests; during these years, non-breeding owls are either absent or extremely inconspicuous. At such times, we find owls using nests of poorer quality and nests closer to roads. Once a male owl has established his territory (it is the male that shows philopatry, the name given to a return to the same territory in subsequent years), then there is presumably greater pressure to make do with whatever nest site is available on the territory.

This retrospective study of my banding records was undertaken to determine the extent of variation encountered in Saskatchewan nest sites, concerning the species of tree, the height of the nest above ground, and, when known, the bird species that built the nest in a previous year.

\section{Methods and Results}

Of 2,923 successful Great Horned Owl nests, with brood size known, 53 were on man-made structures, and the remainder were in trees. I also have data on 11 additional tree nests, seven built by Red-tailed Hawks, two by Ferruginous Hawks and two by Black-billed Magpies, where at least one member of the brood flew and eluded banding, thus removing that nest from our list of regular nests from which brood size is calculated. The 12th additional site was a former Prairie Falcon hole in a river cliff south of Lucky Lake, from which at least one owl was fledged. We did not have a single nest on a broken-off snag, though such have been used in Saskatchewan by Barred Owls, ${ }^{3}$ and are the source of nearly half the Great Horned Owl nests near Cincinnati, Ohio. ${ }^{1,2}$ By the time of the banding visit, usually following strong winds in the preceding week or two, there were six instances where there was no evidence of the initial nest; the young were being cared for on the ground. In 102 instances, the species of tree was not recorded. The height of each nest was recorded, within 10\% error, by comparing the nest height to the six-foot climber as he progressed up the tree, validated by intermittent use of a tape measure and optical measuring device, and by the fairly frequent use of a 20 -foot sectional aluminum ladder. There are 2,746 nests for which height and tree 


\begin{tabular}{|c|c|c|c|c|c|c|}
\hline Tree Species & $n=$ & $\begin{array}{c}\text { height not } \\
\text { recorded }\end{array}$ & $\begin{array}{l}\text { \# with } \\
\text { height }\end{array}$ & $\begin{array}{c}\text { Minimum } \\
\text { height } \\
\text { (feet) }\end{array}$ & $\begin{array}{c}\text { Maximum } \\
\text { height } \\
\text { (feet) }\end{array}$ & $\begin{array}{l}\text { Mean } \\
\text { height } \\
\text { (feet) }\end{array}$ \\
\hline Ash & 30 & 0 & 30 & 10 & 28 & 16 \\
\hline Aspen (live) & 1,710 & 12 & 1,698 & 6 & 59 & 27 \\
\hline Aspen (dead) & 143 & 0 & 143 & 10 & 44 & 24 \\
\hline Birch & 2 & 0 & 2 & 29 & 40 & 35 \\
\hline Black Poplar & 445 & 2 & 443 & 14 & 56 & 35 \\
\hline Caragana & 1 & 0 & 1 & 7 & - & 7 \\
\hline Cottonwood & 19 & 0 & 19 & 12 & 48 & 24 \\
\hline Elm & 33 & 0 & 33 & 9 & 29 & 16 \\
\hline European Poplar & 49 & 2 & 47 & 8 & 56 & 25 \\
\hline Manitoba Maple & 205 & 0 & 205 & 8 & 38 & 19 \\
\hline Scotch Pine & 12 & 0 & 12 & 8 & 34 & 19 \\
\hline Spruce & 57 & 0 & 57 & 8 & 47 & 22 \\
\hline Willow & 56 & 0 & 56 & 6 & 19 & 12 \\
\hline SPC electr. tower & 1 & & 1 & - & 70 & 70 \\
\hline Species Unrecorded & 102 & & & & & \\
\hline Nest fallen down & 6 & & & & & \\
\hline Total and Mean & 2,871 & 16 & 2,746 & 6 & 70 & 25 \\
\hline \multicolumn{7}{|c|}{ Man-made Structures (no height given) } \\
\hline Barn & 39 & & & & & \\
\hline Granary & 2 & & & & & \\
\hline Shed & 2 & & & & & \\
\hline House & 2 & & & & & \\
\hline Platform, box & 7 & & & & & \\
\hline \multicolumn{7}{|l|}{ [SPC tower, above] } \\
\hline Total nests & 2,923 & & & & & \\
\hline
\end{tabular}

species are known, and another 16 for which the tree species is known but height is not available (Table 1).

Identity of the species building the nest was known only when the territory had been visited in a previous year and the builder of the nest observed, or when owl finders visited hawk nests known from previous years to see whether a Great Horned Owl had taken over. Red-tailed Hawks were overwhelmingly the commonest nest providers for the owls; much less common use was made of nests built by the Swainson's Hawk, American Crow and Black-billed Magpie (Table 2).

\section{Discussion}

In Saskatchewan, Great Horned
Owl nests in trees average less than 27 feet above ground, much lower than nests in $\mathrm{Ohio}^{2}$ and Missouri (Henry B. Stuart, pers. comm.), where nests are rarely below 40 feet and sometimes exceed 100 feet above ground (Fig. 1).

\section{Trees}

Our highest tree nest was in a live aspen at 59 feet, while the lowest was at 6 feet (Fig. 2). Dan Neves has since found an owl nest in a Black Poplar, on the east side of Last Mountain Lake, that was 69 feet above ground in a sloping fork; we chose to leave the single young unbanded. Nests in Black Poplars had the highest mean height, 34.5 feet. Nests in willows averaged only 11.5 feet above ground; two were only 6 


\begin{tabular}{|c|c|c|c|c|c|c|c|c|c|c|c|}
\hline \multirow[t]{2}{*}{$\begin{array}{l}\text { Tree } \\
\text { Species }\end{array}$} & \multicolumn{11}{|c|}{ Bird Species That Built Nest } \\
\hline & Uncer. & RTHA & SWHA & AMCR & BBMA & $\mathrm{COHA}$ & FEHA & BRWA & NOGO & GBHE & Total \\
\hline Ash & 26 & & 1 & 2 & 1 & & & - & & & 30 \\
\hline Aspen (live) & 1,245 & 405 & 23 & 20 & 8 & 4 & 2 & 2 & & 1 & 1,710 \\
\hline $\begin{array}{l}\text { Aspen } \\
\text { (dead) }\end{array}$ & 120 & 18 & & 3 & 2 & & & & & & 143 \\
\hline Birch & 2 & & & & & & & & & & 2 \\
\hline $\begin{array}{l}\text { Black } \\
\text { Poplar }\end{array}$ & 187 & 255 & 1 & 1 & & & & & 1 & & 445 \\
\hline Caragana & 0 & & 1 & & & & & & & & 1 \\
\hline Cottonwood & 15 & & 2 & 1 & 1 & & & & & & 19 \\
\hline Elm & 29 & & 1 & 1 & 2 & & & & & & 33 \\
\hline $\begin{array}{l}\text { European } \\
\text { Poplar }\end{array}$ & 39 & 1 & 4 & 3 & 2 & & & & & & 49 \\
\hline $\begin{array}{l}\text { Manitoba } \\
\text { Maple }\end{array}$ & 175 & & 3 & 11 & 13 & 1. & 2 & & & & 205 \\
\hline Scotch Pine & 9 & & & 2 & 1 & & & & & & 12 \\
\hline Spruce & 53 & & & 2 & 2 & & & & & & 57 \\
\hline Willow & 27 & & 26 & 3 & & & & & & & 56 \\
\hline Unknown & 101 & 1 & & & & & & & & & 102 \\
\hline $\begin{array}{l}\text { Nest fallen } \\
\text { down }\end{array}$ & 6 & & & & & & & & & & 6 \\
\hline $\begin{array}{l}\text { SPC electr. } \\
\text { tower }\end{array}$ & & 1 & & & & & & & & & 1 \\
\hline Total & 2,034 & 681 & 62 & 49 & 32 & 5 & 4 & 2 & 1. & 1 & 2,871 \\
\hline
\end{tabular}

feet above ground, within easy reach (Table 1). The three lowest nests were all in the southern third of the province, one in a live aspen in a ravine near Bulyea and two in willows west of Swift Current, in relatively open country.

Trees used most often were those occurring naturally in the parkland region of the province - Trembling Aspen and Black Poplar. Next were domesticated trees, led by the Manitoba Maple or Box Elder, followed by varieties of spruce, European poplar and elm (Table 1).

Throughout most of North America, as in Saskatchewan, Red-tailed Hawks are the usual builders of nests used in subsequent years by Great Horned Owls. Red-tail nests may be somewhat over-represented in my sample, because their nests are large and conspicuous, and because some finders began their owl nest search each year by visiting known hawk nests of previous years. Magpie nests may also be slightly over-represented, since they are easy to identify on the basis of structure alone; owls nest on top of magpie nests, or in the nest cup if part of the roof has disintegrated (Table 2).

\section{Man-made structures:}

Of special interest are the manmade structures. The most unusual location and our highest nest, 69.8 feet above ground, was on the arm of a tower on a 230,000 volt Saskatchewan Power Corporation electrical transmission line east of Saskatoon (Fig. 3). The original nest had been built on the tower crossarm by a Red-tailed Hawk in 1979, 


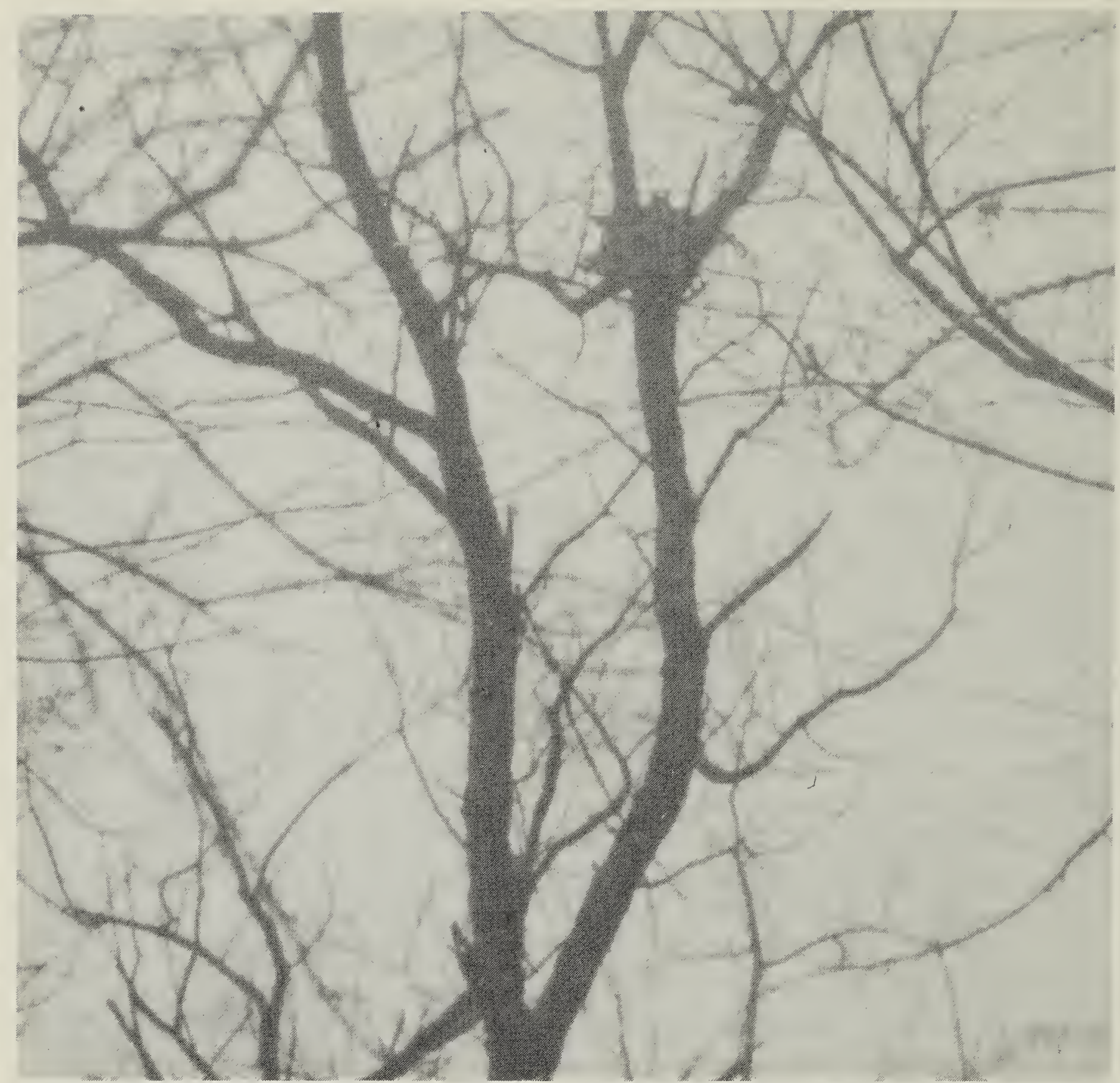

Figure 1. Great Horned Owl on nest, 65 feet above ground, Lee's Summit, Missouri, 4 April 1965.

Henry B. Stuart

and was used again successfully by the hawk in 1980; we chose not to risk our lives to band nestling hawks. In 1981, however, when the owls took over the nest, we obtained the services of lineman Peter Sielski, Saskatchewan Power Corporation, who went with us on a sunny, warm day, and advised us to wear thick, dry gloves to combat the electrical current that hummed through all parts of the tower. Without Sielski's presence and good advice, bander Dr. Bill Barrie would have sat on the crossbar to band the single nestling and thereby would have placed his feet dangerously close to the hightension wires. ${ }^{6}$
One nest north of Dilke was built on Wallace and Sharon Polsom's 3year-old house (Fig. 4), which that winter happened to be unoccupied. The young owls were raised successfully even though the family visited the house frequently; the Polsoms did not take up residence in the house until after the owls had fledged. (Two of the three fledglings were electrocuted on the power transformer in the same yard that summer.) Another owl pair used the windowless attic of a long-deserted farmhouse west of Craik. Two used granaries, one laying its eggs on top of a slight hollow in a large pile of wheat. 


\section{Great Horned Owl nests Live Aspen}

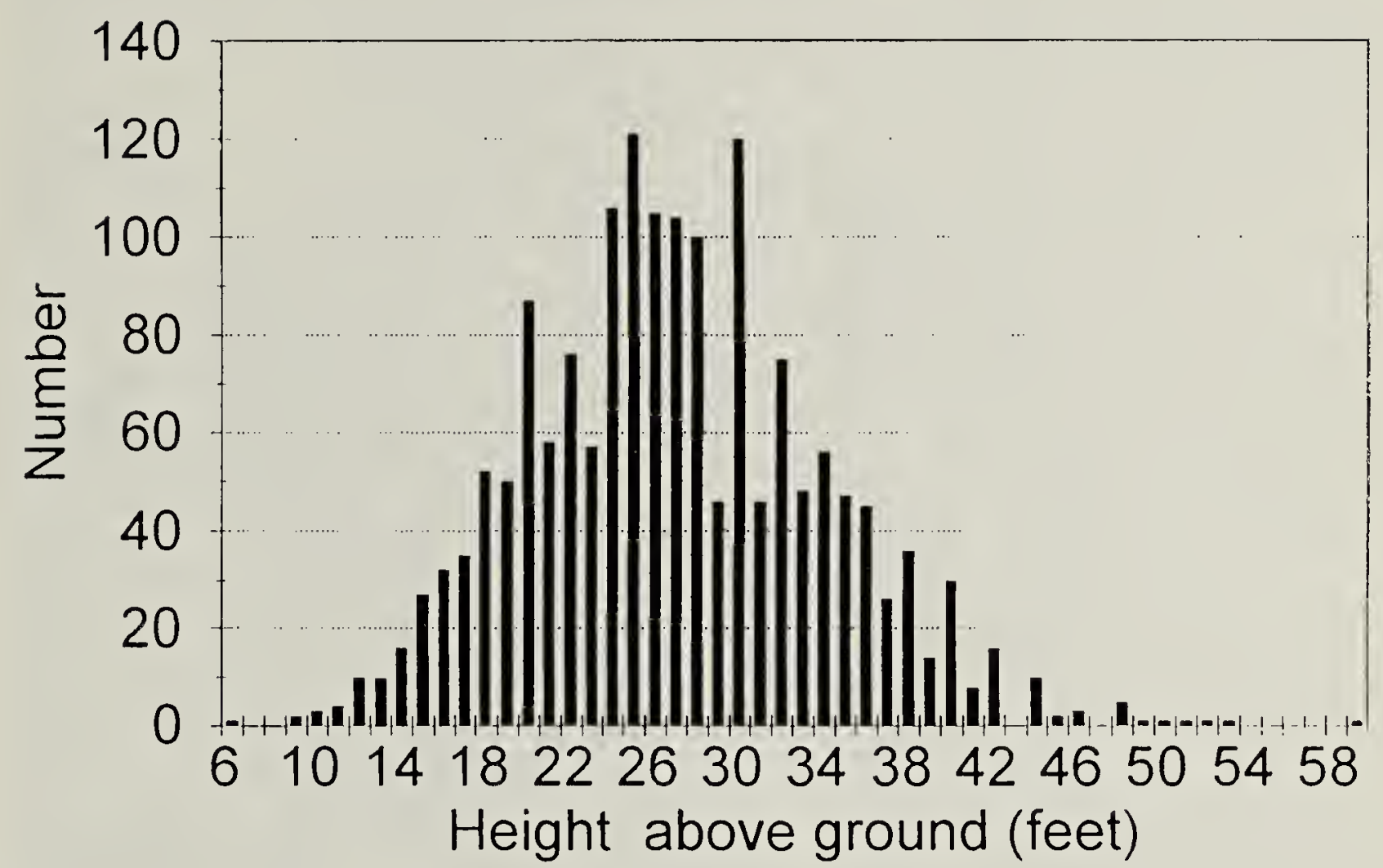

Figure 2. Graph to show distribution of heights of owl nests in aspen.

There were seven usages of boxes or platforms - but no use of the 12 platforms put up by the Saskatoon Junior Natural History Society in 1971 just as owl numbers were on their 10-year downturn. The platform built near Wynyard by the late Bob Gillard had an especially interesting story. A large aspen "bluff," south of the Yellowhead highway, had been used consistently each year for 40 years by Red-tailed Hawks and by Great Horned Owls. Rarely, the owl pair used the same hawk nest for two successive years, but more often the owl took over the most recent hawk nest, forcing the hawk pair to build a new nest or refurbish an earlier one. In late summer 1976, high winds blew down both the hawk tree and the tree used by the owl, so Bob Gillard placed a box, partly filled with sticks, 21 feet above the ground in a Black Poplar crotch. The owls took up residence and three young were banded in the box on 15 May 1977 (Fig. 5). After
Bob's untimely death, his daughter, Shirley Norlin, and granddaughter Sharon Norlin, watched the box. In spite of new hawk nests available each year, the owls used the box on at least two further occasions, with three young banded on 25 May 1980, and 17 May 1981.

Other boxes or platforms were placed and used in Joe Plamondon's farmyard at St. Front, at Jane Pattison's at Lone Rock, and near Valley Centre by Wayne and Don Renaud. When a nest blew down on the golf course at Coteau Beach, Earl Brown put up a platform, with a large tire as its base. All of these fledged young successfully.

Barns formed the majority of manmade structure nest sites. A cupola with a broken window, high above the loft in the Hassman barn west of Cymric, just over a mile from the shore of Last Mountain Lake, was 


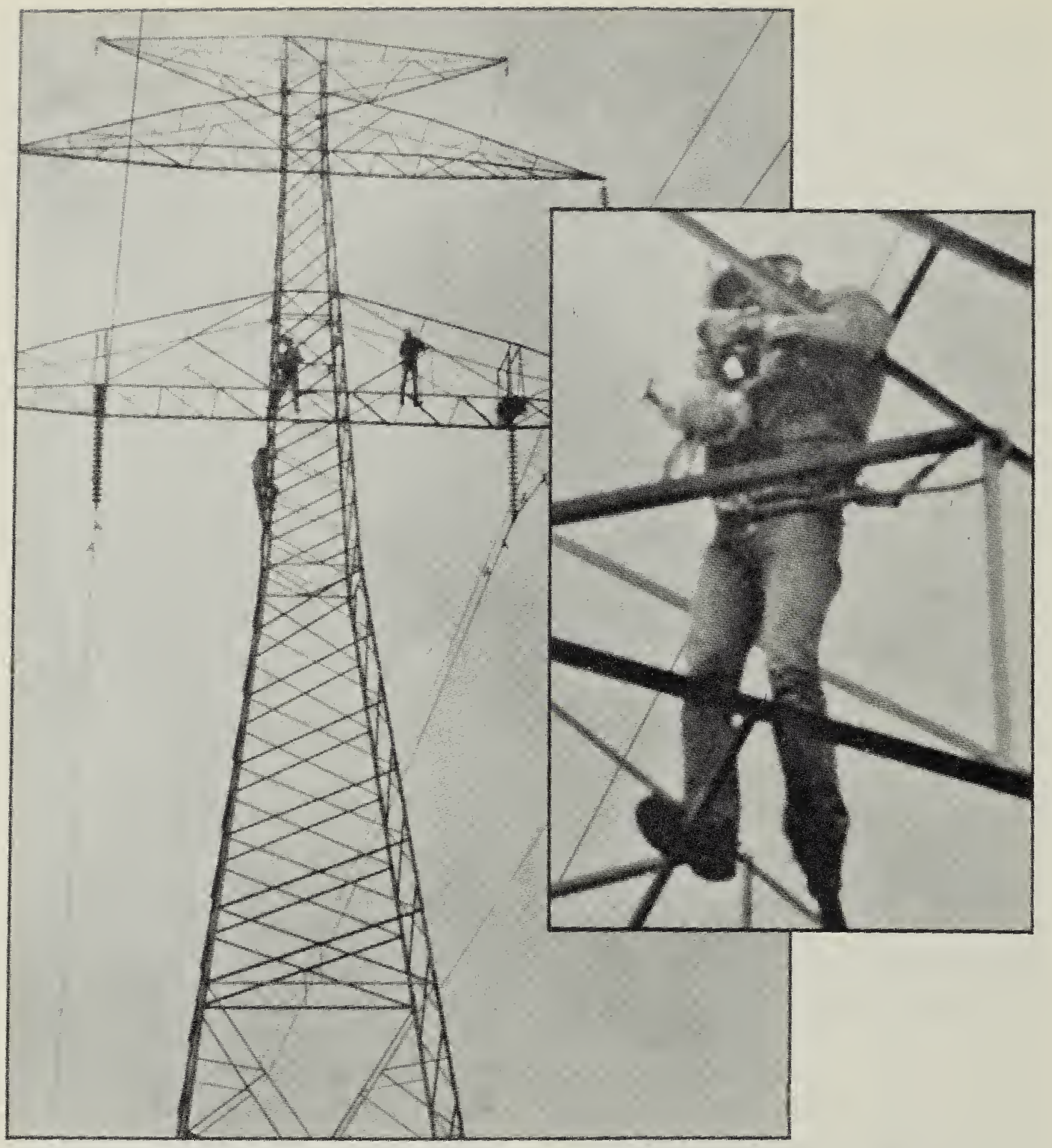

Figure 3. SPC Tower at time of banding of Great Horned Owlet, 12 May 1981

Chris Escott 


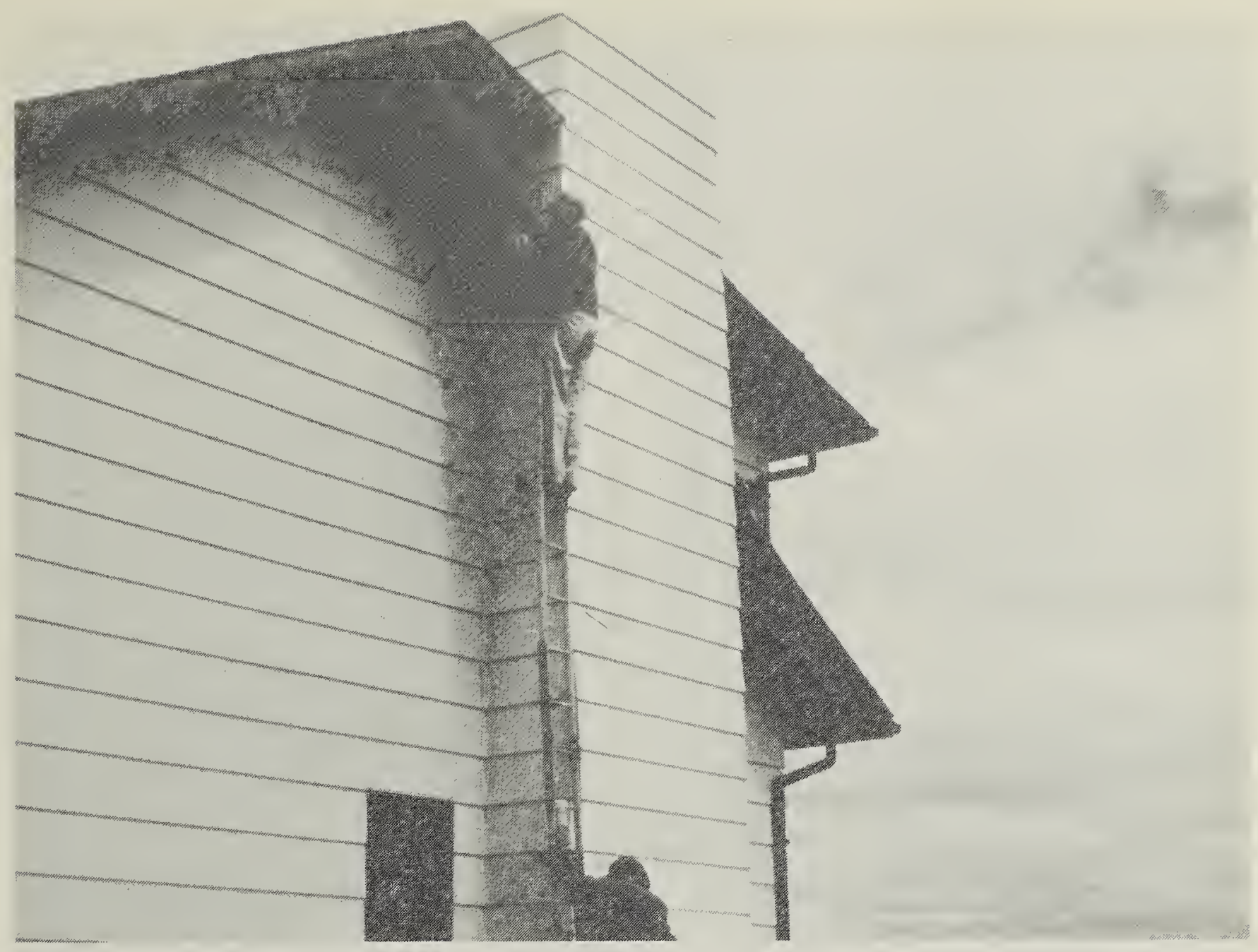

Figure 4. Owl nest on sloping lower roof segment (opposite Houston's head) on temporarily unoccupied Polsom house, north of Dilke, 13 May 1989 Kelly Wylie

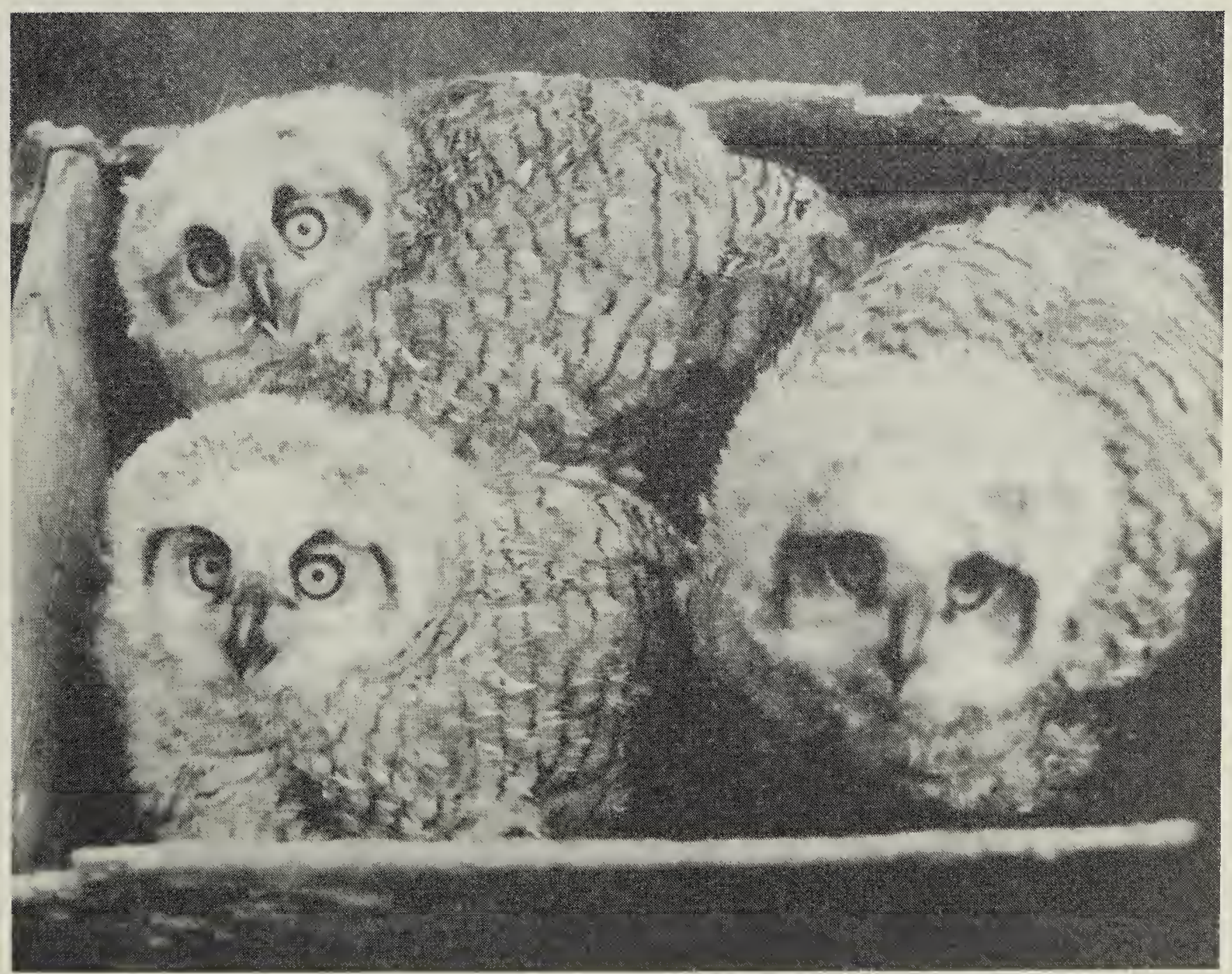

Figure 5. Three nestling owls in coop box, placed 21 feet above ground in black poplar, by Bob Gillard. 15 May 1977

C.S. Houston 


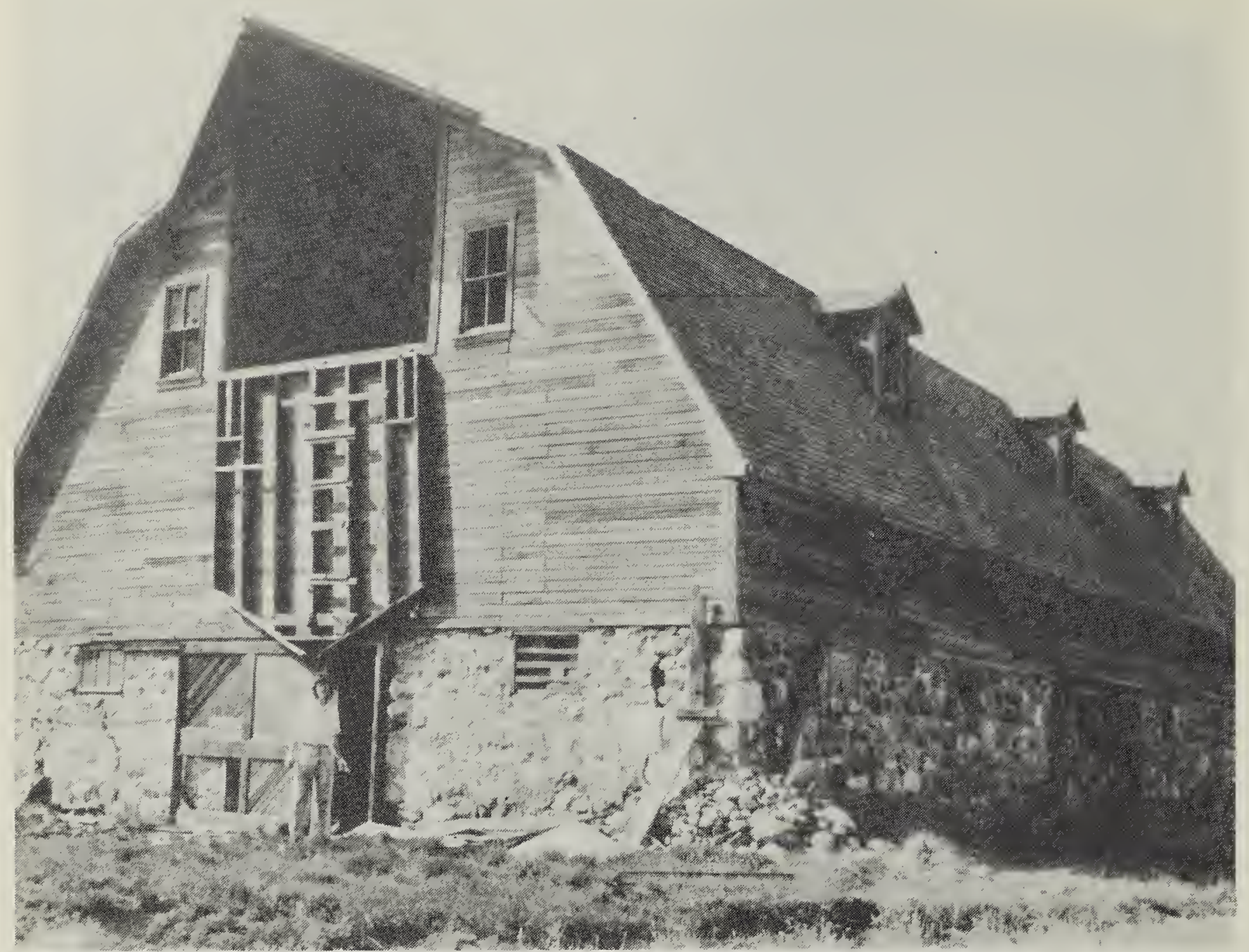

Figure 6. Hassman barn, west of Cymric (external view)

C.S. Houston

used successfully by owls for at least 17 years: 1969-72 inclusive, 1977, 1979 and 1981-91 inclusive (Figs. 6 and 7). With large numbers of birds migrating north along the nearby eastern shore of the lake, these owls appeared well fed. During 17 attempts, all successful, the owls fledged 41 young, for a slightlyabove-average 2.4 young per nest attempt. Raccoons moved into the deserted farmyard in 1992, and we suspect may have destroyed the nest and thus caused the owls to move away. A single owl was seen at the barn in the spring of 1996, but it did not nest.

Other barns near Laura and south of Biggar have been used in successive years. The Clark Jones barn west of Duval was used in two consecutive years. Owls were banded only once in barns near Aylesbury,
Beechy, Bladworth, Carmichael, Conquest, Demaine, Eston, Raymore, Richlea, Saskatoon, and Skull Creek. A very old, low, log barn near Yellow Creek was only shed-height, so that one could reach into the nest in the "rafters." A nest in the hamlet of Isham was not in the barn building proper, but was wedged behind a formerly movable sliding loft door.

The Great Horned Owl, which often lays its eggs in the last week of February or first week of March, no doubt timed so that the young may be well fed on juvenile hares, is well served by not having to build a nest so early in the year. Of necessity, individual owls are extremely flexible in their choice of nest sites.

\section{Acknowledgements}

I wish to thank hundreds of owl nest finders over many years, and 


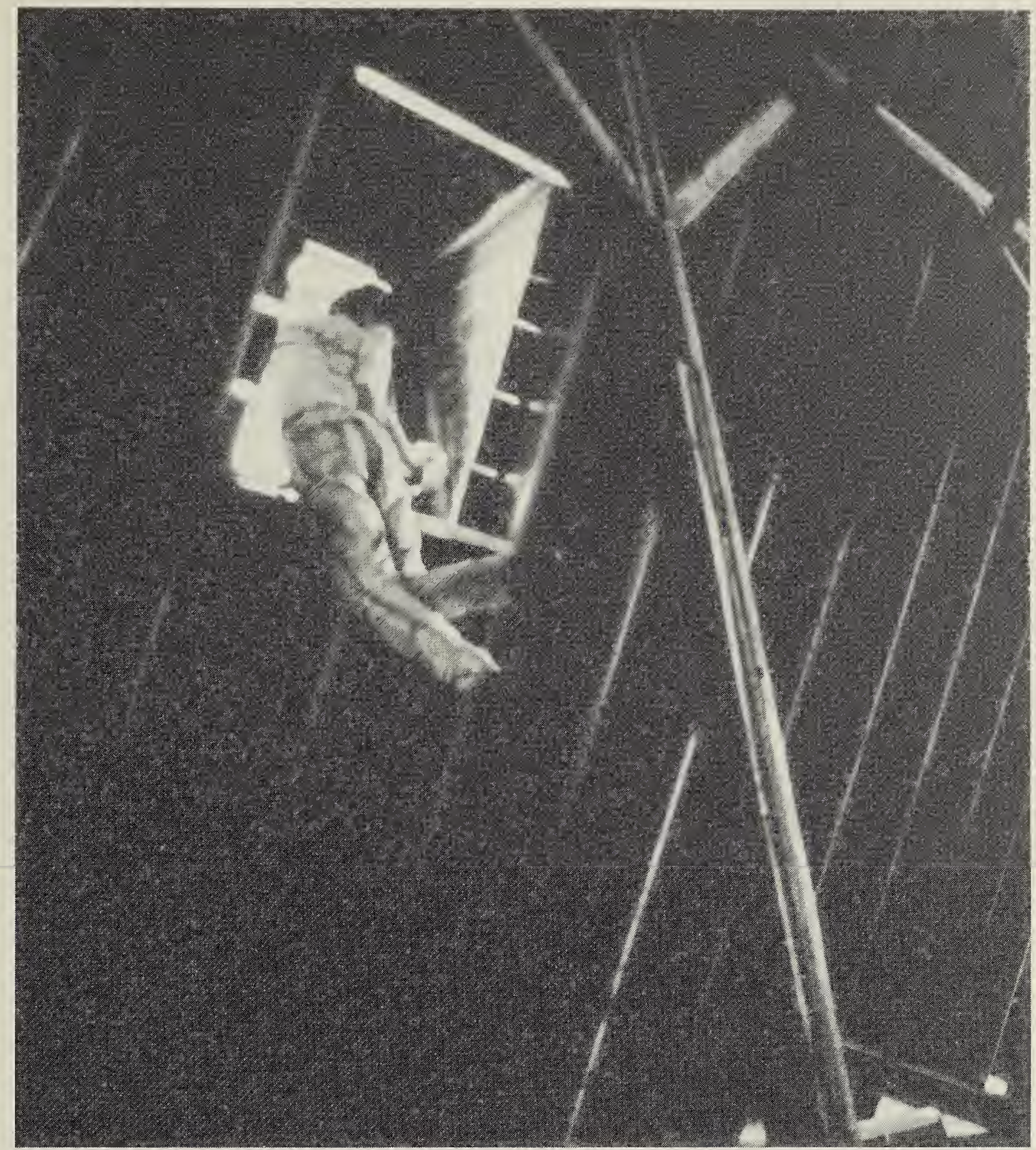

Figure 7. Interior view of cupola of Hassman barn

C.S. Houston

the many helpers and climbers, too numerous to mention. An anonymous reviewer offered helpful improvements. Henry B. Stuart of Summit, Missouri, provided Figure 1.

1. AUSTING, G.R., and J.B. HOLT, JR. 1966. The world of the Great Horned Owl. J.B. Lippincott, Philadelphia, p. 86.

2. HOLT, J.B., JR. 1996. A banding study of Cincinnati area Great Horned Owls. J. Raptor Res. 30: (in press).
3. HOUSTON, C.S. 1961. First Saskatchewan nest of Barred Owl. Blue Jay 19:114-115.

4. HOUSTON, C.S., and C.M. Francis. 1995. Survival of Great Horned Owls in relation to the snowshoe hare cycle. Auk 112:44-59.

5. NEWTON, I. 1979. Population ecology of raptors. Buteo Books, Vermilion, South Dakota.

6. ZELDIN, M. 1981. SPC tower home for owls. Hi-Lines 35(11):9-10. 